THE UNIVERSITY

OF ILLINOIS

LIBRARY

580

F45e

no. $1-10$ 
Return this book on or before the Latest Date stamped below.

\section{University of Illinois Library}

MAY 261954

$r+3-7$ y

DEC 101989

NoV 131987 



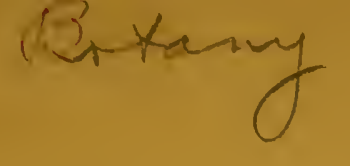

\section{FIGS}

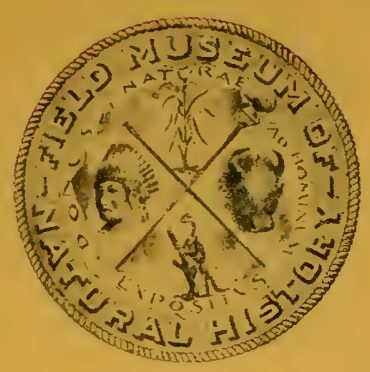

BAIYERSTYY OF :LLMOIS LIBRARY

AUG 161922

FIELD MUSEUM OF NATURAL HISTORY

CHICAGO

1922 



$$
\begin{aligned}
& 500 \\
& F 45 l \\
& n 0.1-10
\end{aligned}
$$

WIVERSIT" of " 1.6 ,

AUG $16 \quad 1922$ 


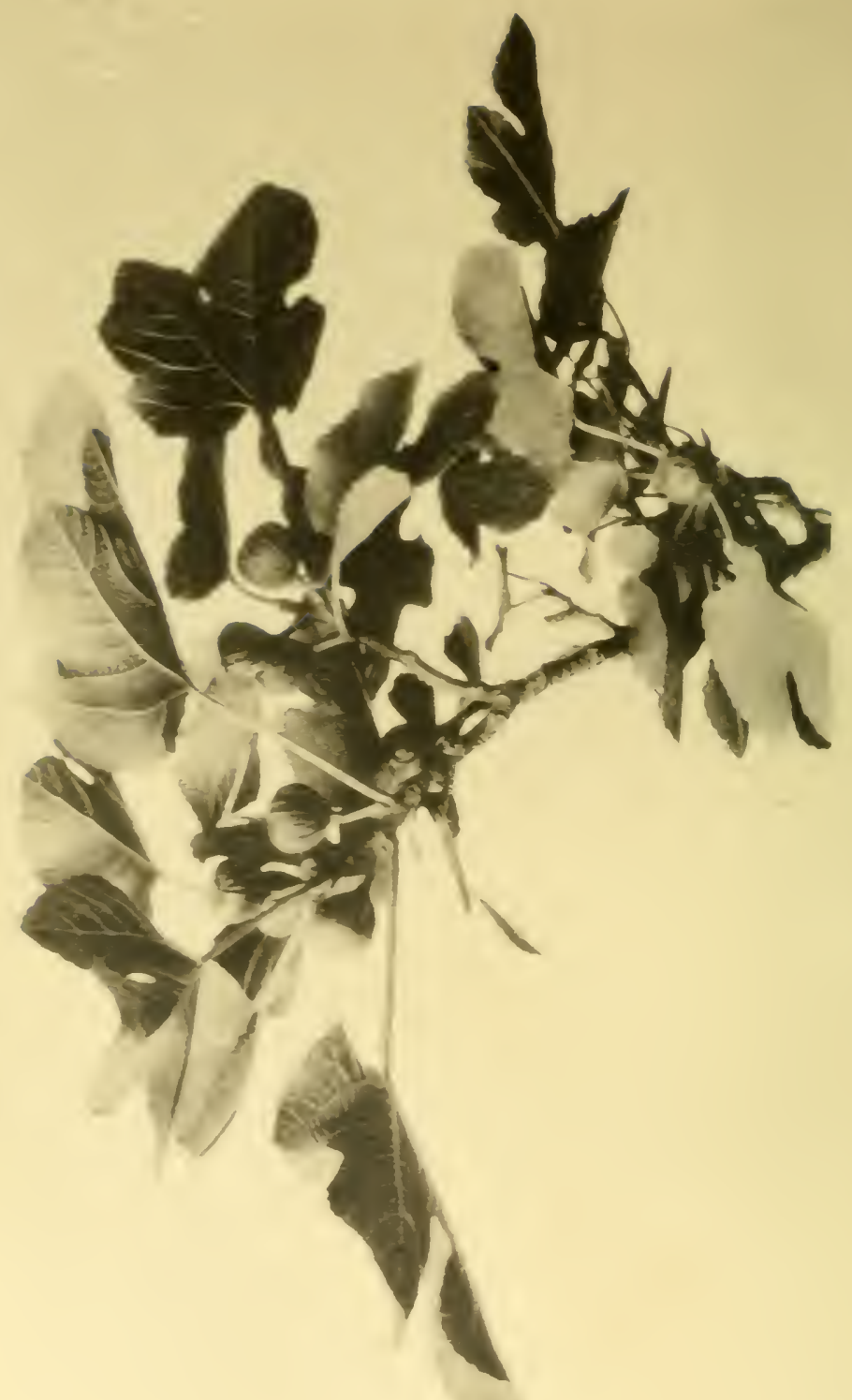




\section{0 \\ F45 \\ $n 0,1-10$}

\section{Field Museum of Natural History}

DEPARTMENT OF BOTANY

CHICAGo, 1922

\section{Figs}

"The wild firs upon the fig trees contain a creature called psen: this is at first a little worm. and afterwards having ruptured the case the psen flies out. and leares it behind. It then pierces the unripe firs, and causes them not to fall off, wherefore gardeners place wild fruit near the cultirated kinds, and plant the wild and cultivated plants near each other."-Aristotle, Histors of Animals. B. V., Ch. XXVI 3.

Botanically the figs are a subdivision of the mulberry family. They are peculiar in not having their flowers exposed, like most flowering plants, but concealed within a hollow, urn-shaped receptacle which has precisely the appearance of a young fruit. The apparent absence of flowers is often a matter for comment. An old Chinese writer on Materia Medica and Natural History in discussing the fig calls it the "fruit without flower." In reality the flowers are numerous but insignificant in size and in appearance. All other members of the family to which the figs belong have, like the mulberry, the flowers and the individual fruits on the outside.

Some 600 species of wild figs have been described to date. A few of them are cultivated or well-known plants, such as the rubber plant which in its normal habitat is a rubber yielding tree, the Banyan tree which with its numerous proproots may spread over an acre or more of ground, and the sycamore fig that furnished the everlasting wood for the cofins of the Pharaohs. The vast majority of figs, howerer, grow in semi-tropical and tropical forests and jungles as shrubs, trees, or 
even as vines. Two species grow native in the subtropical, southern part of Florida. One of them is a so-called "strangling fig." These begin their lives as parasites on other trees, growing at first much like the mistletoe, but eventually sending their own roots to the ground.

The cultivated fig (Ficus carica) is a native of Semitic Asia, perhaps particularly of southern Arabia, but occurs also in Syria and in Palestine. Smyrna was as famous for its figs in ancient times as it is now. From wester'n Asia the Phoenicians and later the Arabs carried the fig throughout the entire Mediterranean region. The old Greeks scoffed at the barbarians who did not have figs and wine. Romulus and Remus, according to tradition, were suckled by a she-wolf under a fig tree. In ancient lore the fig occupied a place such as does our more familiar apple tree of the Garden of Eden. Before the appearance of man, figs grew in Europe and in North America. Leaves and fruits like those of the cultivated fig have been found fossil in France. With the Glacial Period the fig of course disappeared from the modern temperate zone those which now grow in Europe were all introduced horticulturally. Figs have long been grown in China, having been brought by way of Persia from Asia Minor. In modern times the cultivated fig has been introduced into many lands. It is grown in South and Southwest Africa, in South America, and in Australia. It has been grown in Sussex in England. It is successfully cultivated in the United States, especially in California and in the Gulf Region, particularly in Texas. In African Sudan where the fig has failed to grow on its own roots, it has been grown budded on the more tropical sycamore fig.

The cultivated fig is ordinarily a rapidly growing small tree with palmately lobed leaves and with a soft 
wood. It lives sometimes to a great age and then reaches large dimensions. It may be uncommonly productive and is said to bear at times a fruit in every leaf-axil, though part of such a huge crop is apt to drop before maturity.

As in the case of most cultivated fruits there are many varieties. Besides the common fig, called mission figs in California, and the well-known Smyrnas, a California writer lists Adriatic, Eriocyne, Cordelia, and San Pedro figs. The popular distinction into two kinds is on the basis of color, purple or "black" figs and yellow or" "white" figs. The former are usually less sweet and are consumed while fresh. The figs which come dried and packed in boxes or "drums," such as the imported Smyrna figs, are of the white variety. They are preserved like raisins or dates by their own high sugar content.

The fig fruit is a hollow, fleshy receptacle, with a small opening or "eye" in the top furnishing the only point of entry to the interior cavity. Ordinarily this opening is almost entirely closed and barred on the inside by a zone of small, interlocking scales. The inner wall of the receptacle bears the very numerous, small, simple flower's which in the edible fig are all of the female or pistillate kind, more or less perfect. As these grow old and elongate, they completely fill the cavity. Each one of them normally matures a single small dry seed which in some cultivated figs is always sterile, in other's fertile when the flowers have been pollinated. The fruit of some varieties of the cultivated fig "ripens," i. e., the receptacle becomes soft, fleshy and edible, without pollination. The fruit of other's will not ripen unless pollinated.

Pollination is a normal occurrence in the wild fig only. This, in contrast to the edible fig (Ficus) beal's partly inedible fruit and is known as the goats-fig-tree, 
"Caprificus" or Caprifig. It is also known as the "male fig" because its figs or flower receptacles contain male flowers in addition to the others. Female trees of the wild fig also exist but are very scarce. The edible fig is undoubtedly derived from such. The male flower's of the Caprifig are situated in the upper part of the fig cavity, immediately below the scales, which here as in the edible fig, bar the opening to intruders.

The insect which ordinarily inhabits the interior of the fig cavity is the minute Fig Wasp (Blastophaga grossorum, family Chalcidae). Through the course of ages of association (fossil figs have been found in remains of the Cretaceous period) the life history of the fig and of the minute wasp have become inextricably entangled. Complete interdependence has been established between them, so that each is necessary for the existence of the other. Without the wasp the wild fig would soon become extinct, for there would be no maturing of seed, and, vice versa, in the absence of the wild figs there would be no fig wasps hatching. The female fig wasp enters the young caprifig in which at a certain period the orifice is relaxed, lays its eggs in the short-styled flower's near the base of the cavity and dies within the fig. These flowers are known as gall flowers. The habit of response to the visitations of the fig wasp has proceeded to the stage of anticipation, for gall flower's are not normal flowers that become gall flowers through the egg-laying of the insect, but are already present as such, though barren and useless till the puncture of the wasp supplies them an inhabitant in the shape of a wasp grub.

The eggs hatch into male and female wasps. The small, yellow, wingless males mature first, bite holes in their galls and crawl out into the cavity of the fig. They soon cut holes in the gall flowers containing the 
still immature females, impregnate them and shortly die within the fig, as did the mother wasp.

Their sisters, the female wasps, are darker, of a brown color and winged. In due course they hatch and immediately set about leaving the cavity of the fig within which there is no room for them to spread their wings. To reach the orifice of the fig they must pass the male flowers and become dusted with the pollen that matures at the very time of their hatching and departure.

Once in the open air their wings soon dry and each young female wasp is off in search of an immature fig in which to deposit eggs. A suitable one found, the wasp proceeds to cut a notch in one of the outer scales for better access, then makes its way inside. In the process the wasp generally loses its wings. These are apt to stick in the opening, so that an inhabitated fig may be recognized by their presence. The pollen carried by the insect is brushed off on the stigmas of the long-styled flowers within. Eggs can be properly placed only in figs of the Caprificus kind, where gall flowers are present.

Both the wild and the cultivated fig usually bear three crops a year. As insects emerge from one crop of maturing Caprifigs they ordinarily find green fruit of the next crop ready to receive them. Each crop is thus pollinated with pollen of the preceding crop. An interval of about two months elapses between the entrance of the egg-laying fig wasp into the young fig and the emergence of her progeny from the ripe one. The same interval of time separates the receptive stage of the female fig flowers and the ripening of the pollen in the male flower's, completely excluding the possibility of self-pollination. The last of the fig wasps of the year deposit their eggs in young fruit which stays on the trees until spring. 
To prevent the dropping of fruit of the edible fig before maturity, it is an ancient practice among fig grower's to hang branches of the wild fig tree, or strings of ripe Caprifigs, in the trees of the fig orchard. The fig wasps will then enter the young edible figs and bring about pollination with the Caprifig pollen. The true Smyrna fig absolutely requires pollination to ripen its fruit. Fig trees of this variety grown in California continued to drop their immature fruit for over twenty years till the wild fig with its fig wasp was introduced and the so-called "caprification" was made possible. In Mediterranean countries Caprifigs for the purpose of caprification are an article of commerce at times bringing a higher price than edible figs. It has often been stated on apparently good botanical authority that the practice is of doubtful utility. According to the California zoologist, Eisen, who has done much to clear up this question, the confusion is due to a failure to discriminate between the varieties which require and those which do not require pollination in order to mature their fruit. The latter kind are grown altogether in some localities, as in southern France.

The ancients who observed the fig wasp and well knew that it had something to do with the ripening of the fruit, sought to account for it in accordance with the ideas of their time., e. g., "the wasps suck up the superfluous humor's," "they enlarge the eye and permit the fertilizing air to enter."

The German botanist, Solms-Laubach was the first to investigate thoroughly the flowers of the fig and extended his inquilies to some of the numerous species of wild Ficus. Many of these have been studied since and relations have been found to exist between plant host and insect tenant similar to those observed in the cultivated fig. The insects associated with the wild figs are all closely related to the fig wasp of the Capri- 
fig but distinct and different in the various species of the genus Ficus. It would seem probable that most, if not all, of the six hundred or more species of wild figs throughout the world are as dependent for their continued existence on their respective fig wasp guests as is the Caprifig.

B. E. DAHLGREN.

Exhibits in the Field Musenm pertaining to the Mulberry Family and the Fig are to be found in the Department of Botany, Halls 28 and 29, particularly, a reproduction of a fruiting branch of the Cultivated Fig, an enlarged section of a young flower receptacle, an enlarged section of a Caprifig with the male and female Fig Wasps, wood and rubber of Ficus, etc.

In the Department of Geology, Hall 1S, are to be seen fossil Figs, of the Cretaceous period, from Wyoming and Kansas. 
UWIVERSTI of :! AUG AUG 161922 
.

$\frac{1}{4}$

$\therefore$ 



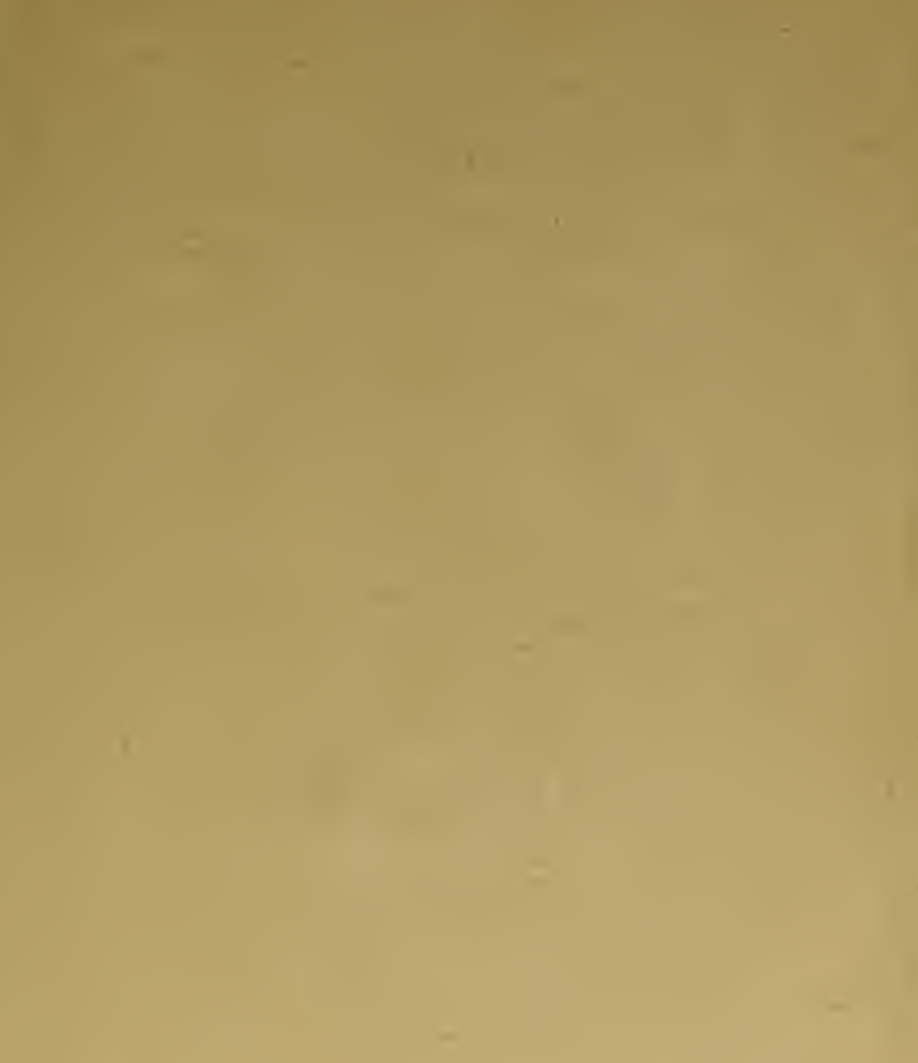


UNIVERSITY OF ILLINOIS-URBANA

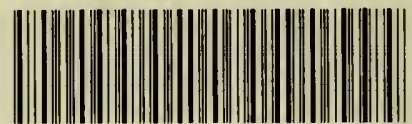

30112033629384 